\title{
Surgical revascularization for acute coronary syndromes: a narrative review
}

\author{
Joseph H. Joo' ${ }^{1}$ Joshua M. Liao², Faisal G. Bakaeen³, Danny Chu \\ ${ }^{1}$ College of Medicine, Texas A\&M University, Bryan, TX 77807, USA. \\ ${ }^{2}$ Department of Medicine, University of Washington, Seattle, WA 98195, USA. \\ ${ }^{3}$ Department of Thoracic and Cardiovascular Surgery, Cleveland Clinic, Cleveland, OH 44195, USA. \\ ${ }^{4}$ Department of Cardiothoracic Surgery, University of Pittsburgh School of Medicine, Pittsburgh, PA 15213, USA.
}

Correspondence to: Prof. Danny Chu, Division of Cardiac Surgery, Department of Cardiothoracic Surgery, University of Pittsburgh School of Medicine, 200 Lothrop Street, C-700 Pittsburgh, PA 15213, USA. E-mail: chud@upmc.edu

How to cite this article: Joo JH, Liao JM, Bakaeen FG, Chu D. Surgical revascularization for acute coronary syndromes: a narrative review. Vessel Plus 2018;2:2. http://dx.doi.org/10.20517/2574-1209.2017.36

Received: 30 Nov 2017 First Decision: 15 Jan 2018 Revised: 23 Jan 2018 Accepted: 24 Jan 2018 Published: 2 Feb 2018

Science Editor: Mario F. L. Gaudino Copy Editor: Jun-Yao Li Production Editor: Cai-Hong Wang

\begin{abstract}
Acute coronary syndrome (ACS) comprises a spectrum of disease that includes unstable angina, non-ST-elevation myocardial infarction, and ST-elevation myocardial infarction. Clinical management of patients with ACS has greatly evolved over the last two decades, but ACS remains an important cause of morbidity and mortality in patients with coronary artery disease. This narrative review describes the indication, timing, and approaches to surgical revascularization in the context of ACS. In particular, the review discusses and compares the utilization of off-pump coronary artery bypass grafting (CABG) vs. conventional on-pump CABG. Other surgical interventions, such as totally endoscopic coronary artery bypass and hybrid coronary revascularization, are also reviewed.
\end{abstract}

Keywords: Acute coronary syndromes, coronary artery bypass graft, off pump coronary artery bypass

\section{INTRODUCTION}

Acute coronary syndrome (ACS) comprises a spectrum of disease that includes unstable angina (UA), non-ST-elevation myocardial infarction (NSTEMI), and ST-elevation myocardial infarction (STEMI), with distinctions based on symptom severity, electrocardiogram patterns, and degree of myocardial necrosis as reflected by cardiac biomarker levels ${ }^{[1-3]}$. In-hospital and long-term mortality have improved largely because of improvements in ACS treatment modalities ${ }^{[4-8]}$. However, ACS remains an important cause of morbidity and mortality in patients with coronary artery disease that is responsible for more than 1 million hospital admissions in the USA annually ${ }^{[9]}$. Concurrently, indications for surgical revascularization in ACS patients

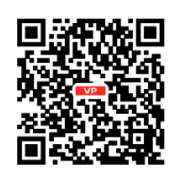


by coronary artery bypass grafting $(\mathrm{CABG})$ as well as the overall management of ACS patients have evolved a great deal over the last 15 to 20 years ${ }^{[4,10]}$.

\section{INDICATIONS FOR SURGICAL REVASCULARIZATION}

For patients with UA or NSTEMI, treatment choices are based on the patient's level of risk as indicated by clinical symptoms, electrocardiogram changes, and cardiac biomarker levels ${ }^{[5]}$. Based on joint guidelines from the American College of Cardiology and American Heart Association, CABG is recommended as primary treatment for patients with significant left main disease or left main equivalent (i.e. significant proximal left anterior descending and proximal left circumflex stenosis) and for patients unresponsive to maximal nonsurgical treatment (Class of Recommendation: I \& Level of Evidence: A) ${ }^{[10]}$. Surgery is also a reasonable consideration in patients with proximal left anterior descending (LAD) stenosis with 1- or 2-vessel disease, presence of complex coronary lesions, and for patients in whom percutaneous intervention is not feasible ${ }^{[11-13]}$.

For patients experiencing NSTEMI and UA, while indications for CABG vs. percutaneous coronary intervention (PCI) are similar to those for patients with stable angina, studies show that high-risk patients with left ventricular systolic dysfunction ${ }^{[14,15]}$, severe 3-vessel disease ${ }^{[16-19]}, 2$-vessel disease involving the proximal LAD, or diabetes mellitus ${ }^{[20-22]}$ should be considered for CABG. Existing guidelines affirm the indications for high-risk patients given the increased chances of long-term survival ${ }^{[23,24]}$. In contrast, the survival benefits of CABG are much more modest in lower-risk patients. Thus, these patients should only be considered for early surgery if they are willing to accept the short-term risks associated with surgical revascularization in exchange for potentially improved functional status.

The accepted first-line treatment for STEMI is PCI or systemic thrombolysis. However, CABG is performed in up to $5 \%$ of STEMI cases ${ }^{[25]}$. In particular, surgery is indicated among patients with good surgical targets but whose hemodynamic instability results in a complicated or failed angioplasty; after a failed fibrinolysis; who have persistent, refractory ischemia; who show evidence of mechanical or valvular disease; who are in cardiogenic shock; or who have life-threatening ventricular arrhythmias and either severe stenosis or multivessel disease $\mathrm{e}^{[10]}$. There is also class II evidence that CABG may be appropriate as primary intervention in patients for whom PCI failed, and it can also be considered in patients with evidence of severe left main or multivessel disease with poor left ventricular function or diabetes.

\section{PROGNOSIS}

Despite improvements over time, in-hospital mortality for patients with acute myocardial infarction (AMI) in the USA remains at 5\% and is even higher among STEMI patients who undergo either PCI or emergency $\mathrm{CABG}^{[26-30]}$. Additionally, NSTEMI patients undergoing surgical intervention have a poorer prognosis than their non-ACS counterparts ${ }^{[31]}$, and the hospital level 30-day risk-standardized mortality rates for patients discharged with AMI remains at approximately $16 \%{ }^{[32]}$. Outcomes for CABG are also worse in patients with ACS than in patients without $A C S^{[4,33]}$. The preoperative troponin I level has been promoted as the strongest independent predictor of short-term death ${ }^{[1,31]}$.

\section{OFF-PUMP CABG}

The advent of off-pump CABG (OPCABG) - which avoids cardiopulmonary bypass and its associated risks - brought the promise of reducing operative risk while producing long-term outcomes that were as good as or better than those of on-pump surgery ${ }^{[34-36]}$. Several studies have since shown short-term outcomes comparable to those of on-pump $\mathrm{CABG}^{[37,38]}$, as well as lower rates of atrial fibrillation, less need for blood transfusions, less renal and neurocognitive dysfunction, and shorter hospital stays in mixed-risk patient 
populations ${ }^{[39]}$. Furthermore, OPCABG is associated with improved resource utilization and increased costeffectiveness ${ }^{[36,40]}$.

However, the relative merits of OPCABG and on-pump CABG remain debatable and there has been national decline in the utilization of $\mathrm{OPCABG}^{[41]}$. Randomized trials have demonstrated that short-term death or complications within a month of surgery occurred at similar frequency, but long-term mortality and complications occurred similarly if not at higher rates in patients undergoing $\mathrm{OPCABG}^{[42,43]}$. Metaanalyses have also failed to demonstrate any significant benefit of OPCABG in mortality rates and showed comparable organ protection to conventional methods ${ }^{[44,45]}$.

Another aspect of understanding the comparative advantages of OPCABG ${ }^{[46,47]}$ is that patients who require intraoperative conversion from off-pump to on-pump surgery or abortion of the OPCABG procedure have poorer outcomes compared to patients undergoing successful OPCABG or on-pump operations ${ }^{[48-51]}$. Additionally, patients who underwent OPCABG generally had fewer anastomoses than their on-pump counterparts, limiting the conclusions that can be drawn about OPCABG in patients with multiple targets and raising concerns about the completeness and effectiveness of revascularization in $\mathrm{OPCABG}^{[39,52]}$.

There are limited data regarding primary OPCABG for the treatment of ACS. In two studies, mortality was lower in off-pump vs. on-pump procedures (5\%vs. $24 \%, P=0.015$ and $3.5 \% v s .5 .4 \%, P=0.690)^{[53,54]}$. Additionally, a European study with a cohort of 624 patients demonstrated that stratification and preselection of patients, as well as the timing of the intervention, are crucial considerations for ensuring that only appropriate candidates undergo and derive benefits from the procedure ${ }^{[55]}$. An updated algorithm to stratify patients and better address the issue of conversion from off- to on-pump CABG has been put forth, which may help to reduce the frequency of off-pump to on-pump conversion in ACS patients ${ }^{[54,56]}$.

\section{OTHER POTENTIAL SURGICAL INTERVENTIONS}

It has been approximately two decades since several groups first described endoscopic techniques for less invasive, closed-chest totally endoscopic coronary artery bypass (TECAB) with the da Vinci robotic system $^{[57,58]}$. After a multicenter trial showed promising results, the US Food and Drug Administration approved robotically-assisted TECAB for non-emergent left internal mammary artery to LAD myocardial revascularization ${ }^{[59]}$. Subsequently, there has been interest both in traditional arrested-heart TECAB with cardiopulmonary bypass and in beating-heart, off-pump TECAB with the use of endoscopic stabilizers. Although issues have been raised regarding technical challenges and conversion rates ${ }^{[60-62]}$, there are also data that suggest that with appropriate techniques and experience, excellent graft patency rates can be achieved ${ }^{[63]}$.

More recent advancement in this field is hybrid coronary revascularization (HCR), a procedure that combines PCI with OPCABG via minimally invasive entry through an anterolateral thoracotomy ${ }^{[64]}$. In patients with multivessel and left main disease, HCR has been shown to be comparable to OPCABG performed via midline sternotomy with respect to short- and mid-term outcomes, without significant differences in repeat revascularization rates ${ }^{[64,65]}$.

Although no study has specifically examined the use of TECAB or HCR in the treatment of ACS, they may be alternative techniques to consider as the technology continues to advance and additional data are gathered regarding their outcomes and safety. Currently, only a few medical centers worldwide perform robotic TECAB due to the high complexity of operations, corresponding long learning curves and lack of an endoscopic surgical tradition ${ }^{[6]}$. Therefore, more evidence is needed to quantify the benefits of HCR as an emerging procedure for ACS. 


\section{TIMING OF SURGICAL REVASCULARIZATION}

In most patients with ACS who are to undergo CABG surgery, the procedure is postponed for several days to reduce procedure-related risk ${ }^{[8]}$. The exceptions are patients with life-threatening conditions, such as severe disease or mechanical complications, who undergo early CABG. In another, AMI patients with persistent nonmechanial complications (persistent ischemia, shock), mortality rates when surgical revascularization was performed within $48 \mathrm{~h}$ of AMI were $7.7 \%$ for on-pump procedures performed because of persistent pain, but were negligible in those done more than $48 \mathrm{~h} \mathrm{later}{ }^{[67]}$. Other work looking at patients undergoing CABG after AMI has produced similar numbers and has associated early operation with higher risk in both transmural and non-transmural $\mathrm{AMI}^{[68]}$. There has been some suggestions, however, that even in higher-risk patients, early CABG is associated with very low in-hospital mortality and, therefore, could be considered in appropriate situations ${ }^{[8]}$. For OPCABG, data suggest that patients taken to the operating room within $6 \mathrm{~h}$ from the onset of chest pain are more suitable for off-pump surgery and have a low incidence of conversion to on-pump CABG, which, as mentioned above, carries severe risks and consequences ${ }^{[54]}$.

\section{CONCLUSION}

Though the management of ACS has greatly evolved over the last two decades, the condition remains an important cause of morbidity and mortality in patients with coronary artery disease. Surgical revascularization is favored for more complex and high-risk patients. The merits of OPCABG remain debatable, and further study is needed to quantify the benefits of TECAB and HCR as emerging procedures for ACS.

\section{DECLARATIONS}

\section{Acknowledgments}

The authors would like to thank Stephen N. Palmer, PhD, ELS, for his contributions to the editing of earlier versions of the manuscript, for which he was not financially compensated.

\section{Author's contributions}

Concept/design: all authors

Definition of intellectual content: all authors

Literature search: all authors

Manuscript preparation, editing, and review: all authors

\section{Financial support and sponsorship}

None.

\section{Conflicts of interest}

Dr. Chu serves as an oral board review examiner for The Osler Institute, academic editor for Wolters Kluwer Health, and national proctor for Toray International America, Inc., and the Japanese Organization for Medical Device Development, Inc., none of which have relationship to this manuscript. Dr. Liao, Dr. Bakaeen, and Mr. Joo have no conflicts to disclose.

\section{Patient consent}

Not applicable.

\section{Ethics approval}

Not applicable.

\section{Copyright}

(c) The Author(s) 2018. 


\section{REFERENCES}

1. Adams JE 3rd, Bodor GS, Dávila-Román VG, Delmez JA, Apple FS, Ladenson JH, Jaffe AS. Cardiac troponin I: a marker with high specificity for cardiac injury. Circulation 1993;88:101-6.

2. Alpert JS, Thygesen K, Antman E, Bassand JP. Myocardial infarction redefined - a consensus document of The Joint European Society of Cardiology/American College of Cardiology Committee for the redefinition of myocardial infarction. J Am Coll Cardiol 2000;36:959-69.

3. Antman EM, Tanasijevic MJ, Thompson B, Schactman M, McCabe CH, Cannon CP, Fischer GA, Fung AY, Thompson C, Wybenga D, Braunwald E. Cardiac-specific troponin I levels to predict the risk of mortality in patients with acute coronary syndromes. $N$ Engl J Med 1996;335:1342-9.

4. Bertrand ME, Simoons ML, Fox KA, Wallentin LC, Hamm CW, McFadden E, De Feyter PJ, Specchia G, Ruzyllo W; Task Force on the Management of Acute Coronary Syndromes of the European Society of Cardiology. Management of acute coronary syndromes in patients presenting without persistent ST-segment elevation. Eur Heart J 2002;23:1809-40.

5. Braunwald E, Antman EM, Beasley JW, Califf RM, Cheitlin MD, Hochman JS, Jones RH, Kereiakes D, Kupersmith J, Levin TN, Pepine CJ, Schaeffer JW, Smith EE 3rd, Steward DE, Theroux P, Gibbons RJ, Alpert JS, Faxon DP, Fuster V, Gregoratos G, Hiratzka LF, Jacobs AK, Smith SC Jr; American College of Cardiology/American Heart Association Task Force on Practice Guidelines (Committee on the Management of Patients With Unstable Angina). ACC/AHA 2002 guideline update for the management of patients with unstable angina and non-ST-segment elevation myocardial infarction: a report of the American College of Cardiology/American Heart Association Task Force on Practice Guidelines (Committee on the Management of Patients With Unstable Angina). Circulation 2002;106:1893-900.

6. Van de Werf F, Ardissino D, Betriu A, Cokkinos DV, Falk E, Fox KA, Julian D, Lengyel M, Neumann FJ, Ruzyllo W, Thygesen C, Underwood SR, Vahanian A, Verheugt FW, Wijns W; Task Force on the Management of Acute Myocardial Infarction of the European Society of Cardiology. Management of acute myocardial infarction in patients presenting with ST-segment elevation. Eur Heart $J$ 2003;24:28-66.

7. Antman EM, Anbe DT, Armstrong PW, Bates ER, Green LA, Hand M, Hochman JS, Krumholz HM, Kushner FG, Lamas GA, Mullany CJ, Ornato JP, Pearle DL, Sloan MA, Smith SC Jr, Alpert JS, Anderson JL, Faxon DP, Fuster V, Gibbons RJ, Gregoratos G, Halperin JL, Hiratzka LF, Hunt SA, Jacobs AK; American College of Cardiology; American Heart Association Task Force on Practice Guidelines; Canadian Cardiovascular Society. ACC/AHA guidelines for the management of patients with ST-elevation myocardial infarction: a report of the American College of Cardiology/American Heart Association Task Force on Practice Guidelines (Committee to Revise the 1999 Guidelines for the Management of Patients With Acute Myocardial Infarction). Circulation 2004;110:e82-292.

8. Monteiro P; Portuguese Registry on Acute Coronary Syndromes. Impact of early coronary artery bypass graft in an unselected acute coronary syndrome patient population. Circulation 2006;114:I467-72.

9. Eisen A, Giugliano RP, Braunwald E. Updates on acute coronary syndrome: a review. JAMA Cardiol 2016;1:718-30.

10. Eagle KA, Guyton RA, Davidoff R, Edwards FH, Ewy GA, Gardner TJ, Hart JC, Herrmann HC, Hillis LD, Hutter AM Jr, Lytle BW, Marlow RA, Nugent WC, Orszulak TA, Antman EM, Smith SC Jr, Alpert JS, Anderson JL, Faxon DP, Fuster V, Gibbons RJ, Gregoratos G, Halperin JL, Hiratzka LF, Hunt SA, Jacobs AK, Ornato JP; American College of Cardiology; American Heart Association Task Force on Practice Guidelines; American Society for Thoracic Surgery and the Society of Thoracic Surgeons. ACC/AHA 2004 guideline update for coronary artery bypass graft surgery: summary article: a report of the American College of Cardiology/American Heart Association Task Force on Practice Guidelines (Committee to Update the 1999 Guidelines for Coronary Artery Bypass Graft Surgery). Circulation 2004;110:1168-76.

11. Aldea GS, Bakaeen FG, Pal J, Fremes S, Head SJ, Sabik J, Rosengart T, Kappetein AP, Thourani VH, Firestone S, Mitchell JD; Society of Thoracic Surgeons. The Society of Thoracic Surgeons Clinical Practice Guidelines on Arterial Conduits for Coronary Artery Bypass Grafting. Ann Thorac Surg 2016;101:801-9.

12. Farooq V, van Klaveren D, Steyerberg EW, Meliga E, Vergouwe Y, Chieffo A, Kappetein AP, Colombo A, Holmes DR Jr, Mack M, Feldman T, Morice MC, Ståhle E, Onuma Y, Morel MA, Garcia-Garcia HM, van Es GA, Dawkins KD, Mohr FW, Serruys PW. Anatomical and clinical characteristics to guide decision making between coronary artery bypass surgery and percutaneous coronary intervention for individual patients: development and validation of SYNTAX score II. Lancet 2013;381:639-50.

13. Tarakji KG, Sabik JF 3rd, Bhudia SK, Batizy LH, Blackstone EH. Temporal onset, risk factors, and outcomes associated with stroke after coronary artery bypass grafting. JAMA 2011;305:381-90.

14. Yusuf S, Zucker D, Passamani E, Peduzzi P, Fisher LD, Takaro T, Kennedy JW, Davis K, Killip T, Norris R, Morris C, Mathur V, Varnauskas E, Chalmers TC. Effect of coronary artery bypass graft surgery on survival: overview of 10-year results from randomised trials by the Coronary Artery Bypass Graft Surgery Trialists Collaboration. Lancet 1994;344:563-70.

15. Mock MB, Fisher LD, Holmes DR Jr, Gersh BJ, Schaff HV, McConney M, Rogers WJ, Kaiser GC, Ryan TJ, Myers WO, Killip T 3rd; Participants in the Coronary Artery Surgery Study. Comparison of effects of medical and surgical therapy on survival in severe angina pectoris and two-vessel coronary artery disease with and without left ventricular dysfunction: a Coronary Artery Surgery Study Registry Study. Am J Cardiol 1988;61:1198-203.

16. Yusuf S, Wittes J, Friedman L. Overview of results of randomized clinical trials in heart disease. II. Unstable angina, heart failure, primary prevention with aspirin, and risk factor modification. JAMA 1988;260:2259-63.

17. The BARI Investigators. Seven-year outcome in the Bypass Angioplasty Revascularization Investigation (BARI) by treatment and diabetic status. J Am Coll Cardiol 2000;35:1122-9.

18. Mohr FW, Morice MC, Kappetein AP, Feldman TE, Ståhle E, Colombo A, Mack MJ, Holmes DR Jr, Morel MA, Van Dyck N, Houle 
VM, Dawkins KD, Serruys PW. Coronary artery bypass graft surgery versus percutaneous coronary intervention in patients with threevessel disease and left main coronary disease: 5-year follow-up of the randomised, clinical SYNTAX trial. Lancet 2013;381:629-38.

19. Serruys PW, Morice MC, Kappetein AP, Colombo A, Holmes DR, Mack MJ, Ståhle E, Feldman TE, van den Brand M, Bass EJ, Van Dyck N, Leadley K, Dawkins KD, Mohr FW; SYNTAX Investigators. Percutaneous coronary intervention versus coronary-artery bypass grafting for severe coronary artery disease. N Engl J Med 2009;360:961-72.

20. Jones RH, Kesler K, Phillips HR 3rd, Mark DB, Smith PK, Nelson CL, Newman MF, Reves JG, Anderson RW, Califf RM. Long-term survival benefits of coronary artery bypass grafting and percutaneous transluminal angioplasty in patients with coronary artery disease. J Thorac Cardiovasc Surg 1996;111:1013-25.

21. First-year results of CABRI (Coronary Angioplasty versus Bypass Revascularisation Investigation). CABRI Trial Participants. Lancet 1995;346:1179-84.

22. Weintraub WS, Stein B, Kosinski A, Douglas JS Jr, Ghazzal ZM, Jones EL, Morris DC, Guyton RA, Craver JM, King SB 3rd. Outcome of coronary bypass surgery versus coronary angioplasty in diabetic patients with multivessel coronary artery disease. $\mathrm{J} \mathrm{Am} \mathrm{Coll} \mathrm{Cardiol}$ 1998;31:10-9.

23. Gu YL, van der Horst IC, Douglas YL, Svilaas T, Mariani MA, Zijlstra F. Role of coronary artery bypass grafting during the acute and subacute phase of ST-elevation myocardial infarction. Neth Heart J 2010;18:348-54.

24. Wright RS, Anderson JL, Adams CD, Bridges CR, Casey DE Jr, Ettinger SM, Fesmire FM, Ganiats TG, Jneid H, Lincoff AM, Peterson ED, Philippides GJ, Theroux P, Wenger NK, Zidar JP, Anderson JL, Adams CD, Antman EM, Bridges CR, Califf RM, Casey DE Jr, Chavey WE 2nd, Fesmire FM, Hochman JS, Levin TN, Lincoff AM, Peterson ED, Theroux P, Wenger NK, Wright RS. 2011 ACCF/ AHA Focused Update of the Guidelines for the Management of Patients With Unstable Angina/Non-ST-Elevation Myocardial Infarction (Updating the 2007 Guideline): a report of the American College of Cardiology Foundation/American Heart Association Task Force on Practice Guidelines Developed in Collaboration With the American College of Emergency Physicians, Society for Cardiovascular Angiography and Interventions, and Society of Thoracic Surgeons. J Am Coll Cardiol 2011;57:1920-59.

25. Anderson JL, Adams CD, Antman EM, Bridges CR, Califf RM, Casey DE Jr, Chavey WE 2nd, Fesmire FM, Hochman JS, Levin TN, Lincoff AM, Peterson ED, Theroux P, Wenger NK, Wright RS, Smith SC Jr, Jacobs AK, Halperin JL, Hunt SA, Krumholz HM, Kushner FG, Lytle BW, Nishimura R, Ornato JP, Page RL, Riegel B; American College of Cardiology; American Heart Association Task Force on Practice Guidelines (Writing Committee to Revise the 2002 Guidelines for the Management of Patients With Unstable Angina/ Non ST-Elevation Myocardial Infarction); American College of Emergency Physicians; Society for Cardiovascular Angiography and Interventions; Society of Thoracic Surgeons; American Association of Cardiovascular and Pulmonary Rehabilitation; Society for Academic Emergency Medicine. ACC/AHA 2007 guidelines for the management of patients with unstable angina/non STelevation myocardial infarction: a report of the American College of Cardiology/American Heart Association Task Force on Practice Guidelines (Writing Committee to Revise the 2002 Guidelines for the Management of Patients With Unstable Angina/Non ST-Elevation Myocardial Infarction): developed in collaboration with the American College of Emergency Physicians, the Society for Cardiovascular Angiography and Interventions, and the Society of Thoracic Surgeons: endorsed by the American Association of Cardiovascular and Pulmonary Rehabilitation and the Society for Academic Emergency Medicine. Circulation 2007;116:e148-304.

26. McNamara RL, Kennedy KF, Cohen DJ, Diercks DB, Moscucci M, Ramee S, Wang TY, Connolly T, Spertus JA. Predicting in-hospital mortality in patients with acute myocardial infarction. $J$ Am Coll Cardiol 2016;68:626-35.

27. Matetzky S, Sharir T, Domingo M, Noc M, Chyu KY, Kaul S, Eigler N, Shah PK, Cercek B. Elevated troponin I level on admission is associated with adverse outcome of primary angioplasty in acute myocardial infartion. Circulation 2000;102:1611-6.

28. Giannitsis E, Muller-Bardorff M, Lehrke S, Wiegand U, Tolg R, Weidtmann B, Hartmann F, Richardt G, Katus HA. Admission troponin $\mathrm{T}$ level predicts clinical outcomes, TIMI flow, and myocardial tissue perfusion after primary percutaneous intervention for acute STsegment elevation myocardial infarction. Circulation 2001;104:630-5.

29. Albes JM, Gross M, Franke U, Wippermann J, Cohnert TU, Vollandt R, Wahlers T. Revascularization during acute myocardial infarction: risks and benefits revisited. Ann Thorac Surg 2002;74:102-8.

30. Lee DC, Oz MC, Weinberg AD, Ting W. Appropriate timing of surgical intervention after transmural acute myocardial infarction. $J$ Thorac Cardiovasc Surg 2003;125:115-20.

31. Thielmann M, Jakob H. Surgical revascularization and perioperative management in patietns with non-ST-elevation acute coronary syndromes. Rocz Akad Med Bialymst 2005;50:37-44.

32. Krumholz HM, Wang Y, Chen J, Drye EE, Spertus JA, Ross JS, Curtis JP, Nallamothu BK, Lichtman JH, Havranek EP, Masoudi FA, Radford MJ, Han LF, Rapp MT, Straube BM, Normand SL. Reduction in acute myocardial infarction mortality in the United States: risk-standardized mortality rates from 1995-2006. JAMA 2009;302:767-73.

33. Louagie YAG, Jamart J, Buche M, Eucher PM, Schoevaerdts D, Collard E, Gonzalez M, Marchandise B, Schoevaerdts JC. Operation for unstable angina pectoris: factors influencing adverse in-hospital out- come. Ann Thorac Surg 1995;59:1141-9.

34. Cleveland JC Jr, Shroyer AL, Chen AY, Peterson E, Grover FL. Off-pump coronary artery bypass grafting decreases risk-adjusted mortality and morbidity. Ann Thorac Surg 2001;72:1282-9.

35. Aub-Omar Y, Taggart DP. Off-pump coronary artery bypass grafting. Lancet 2002;360:327-9.

36. Van Dijk D, Nierich AP, Jansen EWL, Nathoe HM, Suyker WJL, Diephuis JC, van Boven WJ, Borst C, Buskens E, Grobbee DE, de Medina EOR, de Jaegere PPT. Early outcome after off-pump versus on-pump coronary bypass surgery: results from a randomized study. Circulation 2001;104:1761-6.

37. Nathoe HM, Van Dijk D, Jansen E, Suyker W, Diephuis JC, van Boven WJ, de la Rivière AB, Borst C, Kalkman CJ, Grobbee DE, Buskens E, de Jaegere PP; Octopus Study Group. A comparison of on-pump and off-pump coronary bypass surgery in low-risk patients. 
N Engl J Med 2003;348:394-402.

38. Reston JT, Tregear SJ, Turkelson CM. Outcomes following off-pump coronary artery bypass grafting. Ann Thorac Surg 2003;76:1510-5.

39. Cheng DC, Bainbridge D, Martin JE, Novick RJ. Does off-pump coronary artery bypass reduce mortality, morbidity, and resource utilization when compared with conventional coronary artery bypass? A meta-analysis of randomized trials. Anesthesiology 2005;102:188203.

40. Puskas J, Cheng D, Knight J, Angelini G, Decannier D, Diegeler A, Dullum M, Martin J, Ochi M, Patel N, Sim E, Trehan N, Zamvar V. Off-pump versus conventional coronary artery bypass grafting: a meta-analysis and consensus statement from the 2004 ISMICS Consensus Conference. Innovations (Phila) 2005;1:3-27.

41. Bakaeen FG, Shroyer AL, Gammie JS, Sabik JF, Cornwell LD, Coselli JS, Rosengart TK, O’Brien SM, Wallace A, Shahian DM, Grover FL, Puskas JD. Trends in use of off-pump coronary artery bypass grafting: results from the Society of Thoracic Surgeons Adult Cardiac Surgery Database. J Thorac Cardiovasc Surg 2014;148:856-63, 864.e1; discussion 863-4.

42. Shroyer AL, Grover FL, Hattler B, Collins JF, McDonald GO, Kozora E, Lucke JC, Baltz JH, Novitzky D; Veterans Affairs Randomized On/Off Bypass (ROOBY) Study Group. On-pump versus off-pump coronary-artery bypass surgery. $N$ Engl J Med 2009;361:1827-37.

43. Lamy A, Devereaux PJ, Prabhakaran D, Taggart DP, Hu S, Straka Z, Piegas LS, Avezum A, Akar AR, Lanas Zanetti F, Jain AR, Noiseux N, Padmanabhan C, Bahamondes JC, Novick RJ, Tao L, Olavegogeascoechea PA, Airan B, Sulling TA, Whitlock RP, Ou Y, Gao P, Pettit $\mathrm{S}$, Yusuf S; CORONARY Investigators. Five-year outcomes after off-pump or on-pump coronary-artery bypass grafting. $N$ Engl $J$ Med 2016;375:2359-68.

44. Møller CH, Penninga L, Wetterslev J, Steinbrüchel DA, Gluud C. Off-pump versus on-pump coronary artery bypass grafting for ischaemic heart disease. Cochrane Database Syst Rev 2012;(3):CD007224.

45. Raja S. Off-pump versus on-pump coronary artery bypass grafting: comparative effectiveness. Comp Effect Res 2015;5:73-9.

46. Al-Ruzzeh S, Ambler G, Asimakopoulos G, Omar RZ, Hasan R, Fabri B, El-Gamel A, DeSouza A, Zamvar V, Griffin S, Keenan D, Trivedi U, Pullan M, Cale A, Cowen M, Taylor K, Amrani M. Off-pump coronary artery bypass (OPCAB) surgery reduces risk-stratified morbidity and mortality: a United Kingdom multi-center comparative analysis of early clinical outcome. Circulation 2003;108:1-8.

47. Mack MJ, Pfister A, Bachand D, Emery R, Magee MJ, Connolly M, Subramanian V. Comparison of coronary bypass surgery with and without cardiopulmonary bypass in patients with multivessel disease. J Thorac Cardiovasc Surg 2004;127:167-73.

48. Patel NC, Patel NU, Loulmet DF, McCabe JC, Subramanian VA. Emergency conversion to cardiopulmonary bypass during attempted off-pump revascularization results in increased morbidity and mortality. J Thorac Cardiovasc Surg 2004;128:655-61.

49. Edgerton JR, Dewey TM, Magee MJ, Herbert MA, Prince SL, Jones KK, Mack MJ. Conversion in off-pump coronary artery bypass grafting: an analysis of predictors and outcomes. Ann Thorac Surg 2003;76:1138-43.

50. Iaco AL, Contini M, Teodori G, Di Mauro M, Di Giammarco G, Vitolla G, Iovino T, Calafiore AM. Off or on bypass: what is the safety threshold? Ann Thorac Surg 1999;68:148614-89.

51. Jin R, Hiratzka LF, Grunkemeier GL, Krause A, Page US. Aborted off-pump coronary artery bypass patients have much worse outcomes than on-pump or successful off-pump patients. Circulation 2005;112:I332-7.

52. Hattler B, Messenger JC, Shroyer AL, Collins JF, Haugen SJ, Garcia JA, Baltz JH, Cleveland JC Jr, Novitzky D, Grover FL; Veterans Affairs Randomized On/Off Bypass (ROOBY) Study Group. Off-pump coronary artery bypass surgery is associated with worse arterial and saphenous vein graft patency and less effective revascularization: results from the Veterans Affairs Randomized On/Off Bypass (ROOBY) Trial. Circulation 2012;125:2827-35.

53. Locker C, Shapira I, Paz Y, Kramer A, Gurevitch J, Matsa M, Pevni D, Mohr R. Emergency myocardial revascularization for acute myocardial infarction: survival benefits of avoiding cardiopulmonary bypass. Eur J Cardiothorac Surg 2000;17:234-8.

54. Kaya K, Cavolli R, Telli A, Soyal MF, Aslan A, Gokaslan G, Mursel S, Tasoz R. Off-pump versus on-pump coronary artery bypass grafting in acute coronary syndrome: a clinical analysis. J Cardiothorac Surg 2010;5:31.

55. Jasinski MJ, Wos S, Olszowka P, Bachowski R, Ceglarek W, Widenka K, Gemel M, Domaradzki W, Deja M, Szafranek A, Golba K, Szurlej D. Primary OPCAB as a strategy for acute coronary syndrome and acute myocardial infarction. Heart Surg Forum 2003;6:31-5.

56. Borde D, Asegaonkar B, Apsingekar P, Khade S, Futane S, Khodve B, Annachatre A, Puranik M, Borgaonkar V, Belapurkar Y, Joshi S. Risk stratification in off-pump coronary artery bypass (OPCAB) surgery - role of EuroSCORE II. $J$ Cardiothorac Vasc Anesth 2015;29:1167-71.

57. Loulmet D, Carpentier A, d'Attellis N, Berrebi A, Cardon C, Ponzio O, Aupècle B, Relland JY. Endoscopic coronary artery bypass grafting with the aid of robotic assisted instruments. J Thorac Cardiovasc Surg 1999;118:4-10.

58. Falk V, Diegeler A, Walther T, Banusch J, Brucerius J, Raumans J, Autschbach R, Mohr FW. Total endoscopic computer enhanced coronary artery bypass grafting. Eur J Cardiothorac Surg 2000;17:38-45.

59. Argenziano M, Katz M, Bonatti J, Srivastava S, Murphy D, Poirier R, Loulmet D, Siwek L, Kreaden U, Ligon D; TECAB Trial Investigators. Results of the prospective multicenter trial of robotically assisted totally endoscopic coronary artery bypass grafting. Ann Thorac Surg 2006;81:1666-75.

60. de Cannière D, Wimmer-Greinecker G, Cichon R, Gulielmos V, Van Praet F, Seshadri-Kreaden U, Falk V. Feasibility, safety, and efficacy of totally endoscopic coronary artery bypass grafting: multicenter European experience. J Thorac Cardiovasc Surg 2007;134:710-6.

61. Bonatti J, Schachner T, Bonaros N, Ohlinger A, Danzmayr M, Jonetzko P, Friedrich G, Kolbitsch C, Mair P, Laufer G. Technical challenges in totally endoscopic robotic coronary artery bypass grafting. J Thorac Cardiovasc Surg 2006;131:146-53.

62. Bolton JW, Connally J. Results of a phase one study on robotically assisted myocardial revascularization on the beating heart. Ann Thorac Surg 2004;78:154-8. 
63. Srivastava S, Gadasalli S, Agusala M, Kolluru R, Barrera R, Quismundo S, Kreaden U, Jeevanandam V. Beating heart totally endoscopic coronary artery bypass. Ann Thorac Surg 2010;89:1873-80.

64. Halkos ME, Vassiliades TA, Douglas JS, Morris DC, Rab ST, Liberman HA, Samady H, Kilgo PD, Guyton RA, Puskas JD. Hybrid coronary revascularization versus off-pump coronary artery bypass grafting for the treatment of multivessel coronary artery disease. Ann Thorac Surg 2011;92:1695-702.

65. Halkos ME, Rab T, Vassiliades TA, Morris DC, Douglas JS, Kilgo PD, Liberman HA, Guyton RA, Thourani VH, Puskas JD. Hybrid coronary revascularization versus off-pump coronary artery bypass for the treatment of left main coronary stenosis. Ann Thorac Surg 2011;92:2155-60.

66. Canale LS, Mick S, Mihaljevic T, Nair R, Bonatti J. Robotically assisted totally endoscopic coronary artery bypass surgery. $J$ Thorac Dis 2013;5 Suppl 6:S641-9.

67. Nunley DL, Grunkemeier GL, Teply JF, Abbruzzese PA, Davis JS, Khonsari S, Starr A. Coronary bypass operation following acute complicated myocardial infarction. J Thorac Cardiovasc Surg 1983;85:485-91.

68. Lee DC, Oz MC, Weiberg AD, Lin SX, Ting W. Optimal timing of revascularization: Transmural versus nontransmural acute myocardial infarction. Ann Thorac Surg 2001;71:1198-204. 